\title{
A Pedagogical Framework for Teaching Chinese College English Learners' Argumentative Writing via Infusion of Critical Thinking
}

\author{
Chunxia $\mathrm{Lu}^{1}$, Rosukhon Swatevacharkul ${ }^{2}$ \\ ${ }^{1}$ Assumption University, Bangkok, Thailand; Yancheng Teachers' University, Jiangsu, China \\ ${ }^{2}$ Assumption University, Bangkok, Thailand \\ Correspondence: Chunxia Lu, Yancheng Teachers’ University, Jiangsu, China.
}

Received: September 7, 2020

Accepted: September 30, $2020 \quad$ Online Published: October 22, 2020

doi:10.5430/wjel.v11n1p1

URL: https://doi.org/10.5430/wjel.v11n1p1

\begin{abstract}
To compose an argumentative writing essay for a Chinese college student is a challenging activity as argumentative writing requires the high-order skills such as analysis, evaluation, reasoning. These skills are also termed as critical thinking skills. Thus this paper proposed to teach Chinese college English learners to compose an argumentative essay through the approach of infusing critical thinking skills into argumentative essay writing classes. It also put forward a pedagogical framework to facilitate Chinese college argumentative writing teachers to develop students' argumentative writing ability.
\end{abstract}

Keywords: argumentative writing, critical thinking skills, Chinese college English learners, a pedagogical framework

\section{Introduction}

In EFL context, argumentative writing skills are always considered to be necessary. It can be seen that argumentative writing ability is tested in main language proficiency tests, such as Chinese National Test for English Majors (TEM), International English Language Testing System (IELTS) and so on. These tests also reveal that argumentation is a crucial skill in higher education for both academic and career success (Nippold, Ward-Lonergan \& Fanning, 2005). However, argumentative writing is never easy. Argumentative writers need to take each of the following elements into careful consideration in order to compose a successful argumentative essay, namely, Claim, My side \& Your side, Evidence, Backing, Rebuttal and Conclusion.

Thus, it is easy to understand that Chinese students' argumentative writing is not satisfying. Here are three main problems. Vagueness: when the students are required to write something, their mind goes blank and find nothing to say. Or they have some vague ideas but they do not know where to go and how to start or what should be put into the argumentative writing. Even when they begin to write, they are unclear about their ideas (Jin, 2011 cited in Sun, 2011). Monotonousness: from the analysis of Chinese college English learners' writing corpus, Liang (2011 cited in Sun, 2011) figured out the lack of variety in argumentative structures, words and ideas in Chinese students' English writings, so their writings are easily analyzed as the writings have a similar pattern in structure and contents. Illogicalness: $\mathrm{Mu}$ (2016) investigated 73 senior students from a local university. They were found feeble in arguing in a precise and deep way during their writing process. Their argumentative essays were minimally developed and poorly reasoned which indicates that they were not skilled in analyzing the issue, generating the sub-argument, and arguing from different perspectives to draw a reasonable conclusion. It is commonly seen that students produce a statement with irrelevant and insufficient evidence to support.

In terms of the reasons behind, it is claimed that the weakness of students' critical thinking skills is one (Sun, 2011; $\mathrm{Mu}, 2016)$ as critical thinking can equip the writers to think in a logical way in order to make an effective and convincing argument. Students are necessarily engaged in the activity of critical thinking in order to compose an argumentative essay. Lack of critical thinking skills will probably lead to poverty in ideas and vulnerability in arguing (Nattawut \& Dumrong, 2019). Thus, in Chinese argumentative writing classes, critical thinking skills are proposed to be trained in order to develop students' arguing ability (Huang, 2010; Wen \& Sun, 2015, Sun, 2019).

\section{Pedagogical Framework}

Critical thinking is a "purposeful, self-regulatory judgment which results in interpretation, analysis, evaluation, and 
inference, as well as explanation of the evidential, conceptual, methodological, criteriological, or contextual considerations upon which that judgment is based" (Facione, 1990). According to Facione (1990), critical thinking cover six skills, namely integration, analysis, inference, explanation, evaluation, and self-regulation.

In terms of how to instruct critical thinking in writing classes, the infusion approach of training critical thinking skills put forward by Ennis (1989) was applied. He defined the infusion approach as the approach of teaching critical thinking skills in an explicit way within a particular discipline. Through infusion of critical thinking, students can figure out what ways of doing are good to practice and what plans are the best ones to adopt. Students can cultivate the habit of thinking, and get familiar with occasions where critical thinking is necessary (Swartz, 2001). Thus during the infusion classes, teachers need to list critical thinking as the obvious learning objectives (Abrami, 2008). The more explicit the instruction objectives are, the more impact it will bring (Swartz, 2001).

The detailed pedagogical framework to guide the infusing practice is based on the theoretical one proposed by Lu (2019). Within her framework, three aspects are included: explicit instruction of critical thinking skills, teacher's feedback and students' reflection. Critical thinking skills are explicitly instructed into students' writing process. Teacher's feedback and students' reflection serve as pedagogical tools intentionally to scaffold students to infuse critical thinking into their own argumentative writing process.

Based on the theoretical framework, the pedagogical framework for teaching argumentative writing by infusing critical thinking skills was proposed in Figure 2.1. Three aspects, explicit instruction of critical thinking, students' self-reflection and teacher's feedback, are elaborated in the following section for the instructional sake.

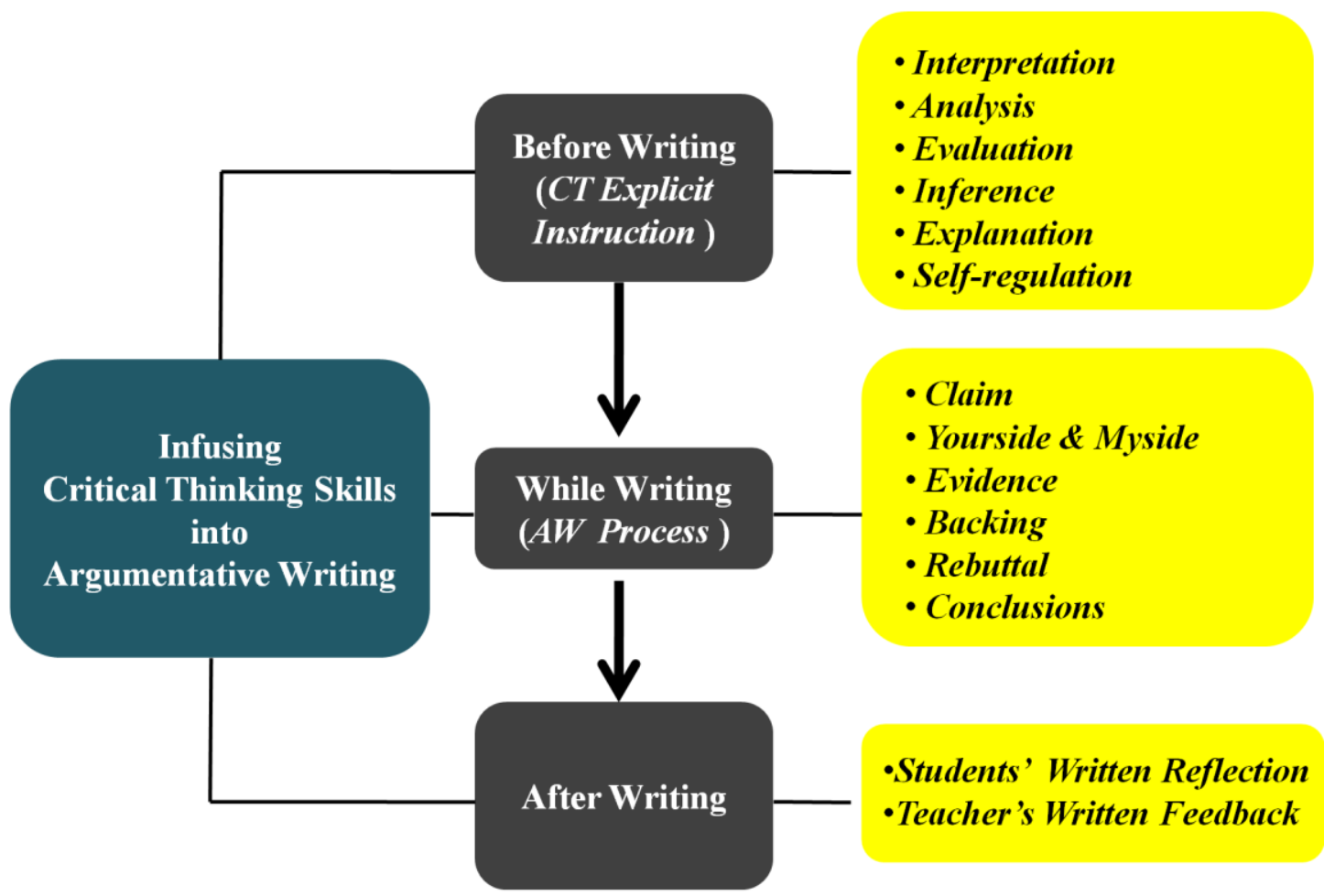

Figure 2.1. Framework for Infusing Critical Thinking into Argumentative Writing Process

\subsection{Explicit Instruction of Critical Thinking}

On the basis of the skill acquisition theory which claims that 'the learning of a wide of skills shows a remarkable similarity in development from initial representation of knowledge through initial changes in behavior to eventual fluent, spontaneous, largely effortless, and highly skilled behavior' (Dekeyser, 2007: p. 97). During the learning process, practice plays an important role as practice lead skill acquisition from an initial learning stage to the eventual proficiency stage. Critical thinking, as a cognitive skill, also needs practice step by step in order to achieve the proficiency level. Thus, during the infusion process, activities to create chances in order to practice critical thinking are designed.

To ensure efficiency of infusion, activities in each class are designed with the guidance of Beyer's six-stage 
instructional frame work for teaching critical thinking skills. These stages are: (a) Introduction, (b) Guided Practice, (c) Independent Application, (d) Transfer and Elaboration, (e) Independent Practice, and (f) Autonomous Use (Beyer, 1987 , p. 75). Table 2.1 shows the detailed stages of infusing critical thinking skills in argumentative writing classes.

Table 2.1. Steps for Infusing Critical Thinking Skills in AWICT Class Adapted from Beyer (1987)

\begin{tabular}{|l|l|l|}
\hline Steps & \multicolumn{1}{|c|}{ Activities } & \multicolumn{1}{c|}{ Objectives } \\
\hline Step 1 & Introduction & $\begin{array}{l}\text { To activate students' knowledge about critical thinking } \\
\text { skills }\end{array}$ \\
\hline Steps 2 & Guided Practice & To aid teacher's instructions of critical thinking \\
\hline Step 3 & Independent Application & $\begin{array}{l}\text { To aid students' infusion of critical thinking skills into } \\
\text { their writing process }\end{array}$ \\
\hline Step 4 & Transfer \& Elaboration & $\begin{array}{l}\text { To ask students to discuss in pairs about the given topic } \\
\text { for applying critical thinking skills }\end{array}$ \\
\hline Step 5 & Independent Practice & To let students draft independently \\
\hline Step 6 & Autonomous Writing & To have students rewrite autonomously \\
\hline
\end{tabular}

\subsection{Students'Self-Reflection in Infusing Process}

Students' reflection is an individual practice to evaluate a particular experience from a new angle for better performance (Hong \& Choi, 2011). The necessity and importance of students' reflection during writing process has been confirmed by many studies (Denny, 2008; Sharples, 1999). During the process of reflection, students' thinking is deepened as reflection helps students to organize ideas in a more logical way and thereby achieves deep understanding and improves writers' performance. Students' reflection is always featured by being exploratory, active and critical. According to Black and Plowright (2010), reflection is "the process of engaging with learning and/or professional practice that provides an opportunity to critically analyze and evaluate that learning or practice" (p. 246). Students need to reflect actively and critically on what has taken place and decide what should do next for a better learning outcome. During the process of reflection, students reflect on their current learning experience actively and then explore the questions from a new and higher lever.

As to how the students reflect during the learning process, Schön (1987) distinguished reflection-in-action from reflection-on-action. Reflection-in-action occurs when students pause in the middle of a learning activity and then take time to rethink the former learning activity and decide on the following learning action. Reflection-on-action takes place after a learning situation when students look back on the choices or strategies made. Compared with reflection-on-action, reaction-in-action is somewhat distractive for a smooth learning process as students are required to pause in the middle of a leaning activity.

For effective reflection, Gibbs (1988) put a reflective cycle during which participants follow six stages: (a) describe what happened in class, (b) tell how they feel about such experience, (c) assess what is good or bad on their learning experience, (d) analyze the impacts of the experience, (e) conclude the whole experience, and (f) make a plan about what they will do in next similar situations. According to Gibbs, some specific questions with vocabulary aid can facilitate participants for better reflection. Moussa-Inaty (2015) also reported that most students preferred to follow the explicit guided questions and would perform better during their reflection. Thus, the paper proposed some questions and vocabulary aid that will help student to reflect on their own reflection practice. Table 2.2 details the questions and vocabulary aid that can be applied into the infusion process. 
Table 2.2. Guidance for Reflective Logs (Gibbs, 1988)

\begin{tabular}{|c|c|c|c|}
\hline \multicolumn{2}{|c|}{ Stages } & Examples of Guided Questions & Examples of Vocabulary Aid \\
\hline 1 & Description & $\begin{array}{l}\text { What happened in class? } \\
\text { What did I learn? } \\
\text { How did I see this before? }\end{array}$ & In class, I did... \\
\hline 2 & Feelings & $\begin{array}{l}\text { How did I fell about the instruction? } \\
\text { What were my feelings? }\end{array}$ & For me, it is useful/ meaningful/ frustrated, etc. \\
\hline 3 & Evaluation & $\begin{array}{l}\text { What was difficult to me? } \\
\text { What was good and what was bad? } \\
\text { How was the instruction different from or similar to } \\
\text { others? }\end{array}$ & I think... is good/ bad/ different/similar as... \\
\hline 4 & Analysis & What impacts did the instruction make? & My skill in... is slightly/greatly improved... \\
\hline 5 & Conclusion & What conclusion can I draw? & $\begin{array}{l}\text { This skill could be essential, useless, important to me } \\
\text { as... }\end{array}$ \\
\hline 6 & Action & $\begin{array}{l}\text { What will I do next time in similar situation? } \\
\text { What steps will I take on the basis of what I have } \\
\text { learnt? }\end{array}$ & As a next step, I need to... \\
\hline
\end{tabular}

\subsection{Teacher's Feedback}

Teacher's feedback is long acknowledged to play a significant role for the improvement of students' writing proficiency as writing itself is complex. Writers have to create a new text instead of coping with an already-constructed one. According to Cole (2006), any response the teacher provides to students' writings in order to promote better performance is defined as feedback. The purpose of teacher's feedback is to reduce the gap between learners' current performance and desired performance. Pedagogically, teacher's feedback is an instructional tool and an assessment method as well. It helps develop students into independent writers and enhance their autonomous writing skills (Hyland \& Hyland, 2006). Teacher's feedback also has potentials to facilitate students' revisions and assist them to learn to write step by step (Harmer, 2004). In a word, successful explicit instruction of critical thinking during argumentative writing process is impossible without teacher's feedback.

Teacher's feedback can be provided orally, in a written form or a written feedback followed by a conference. To writing instructors, written feedback is the most commonly-seen traditional method applied in delivering teacher's response to a piece of writing. However, the task of providing written feedback especially in large classes is time-consuming and laborious. That is why it is commonly seen that teachers just issue a grade instead of giving a comprehensive written response (Dellebovi, 2012; Dixon \& Moxley, 2013). Compared with grading, written feedback serves as an essential role in successful writing instruction, because it has the potential to prompt teacher's individualized response to meet learners' needs at varying levels. However, teacher's feedback is sometimes criticized as it is subjective and heavily depends on teacher's personal judgments since it lacks criteria that grading rubrics have (Hattie \& Timperley, 2007). To combine grading with teachers' written feedback becomes an alternative. Grading as a summative assessment enables writers realize where they are. Written feedback, as a formative assessment facilitates writers to know where the gap is and where they will go.

When the teacher provides written response, the forms of feedback or the contents of feedback need to be carefully chosen since different types of feedback lead to different unpredictable results. Feedback strategies are important. The sandwich feedback method is usually applied to guide the teacher's written comments, that is, Compliment, Criticism, and Compliment (Bergen, Bressler \& Campbell, 2014), which means that the feedback begins with praise, then moves to criticisms and ends with praise again. The method wisely balances the negative feedback and positive feedback since it takes the learners' emotion into consideration. While it is reported that sandwich feedback only benefits the learners' perception not their performance (Parkin, Hepplestone, Irwin \& Thorpe, 2012), but the three steps of giving feedbacks are easily followed and practiced especially for large-scale writing tasks. Then it is modified into Compliment, Recommendation, and Compliment. Herein, criticism is replaced as studies as learners hope to receive feedback which clearly and directly guide them how to make a revision (Bitchener, 2008). Teacher's feedback is supposed to become more fruitful if some recommendations are given to guide future learning instead of critique.

Thus to ensure practicality and increase the value of teacher's feedback, it will be much better to (a) integrate grading with written commentary, and (b) apply the sandwich format with modification when the teacher provides feedbacks in argumentative writing classes where critical thinking skill are explicitly instructed. When writing instructors provide feedbacks, they need to move around two aspects: the text and the writer. To summarize, in order 
to ensure the quality of the teacher's feedback, grading rubrics work together with written comments. Accordingly, in this paper, the teacher's feedback method is proposed in Table 2.3 for facilitating the infusion of critical thinking skills into argumentative writing process.

Table 2.3. Teacher's Feedback

\begin{tabular}{|l|l|l|}
\hline Feedback Approach & \multicolumn{2}{|l|}{ Feedback Strategy } \\
\hline \multirow{2}{*}{\begin{tabular}{l} 
Grading \\
\multirow{2}{*}{$\begin{array}{l}\text { Written Comments } \\
\text { (Modified Sandwich format) }\end{array}$}
\end{tabular}} & $\bullet \quad$ Compliment & \multirow{2}{|l|}{ Text-oriented } \\
\cline { 2 - 3 } & $\bullet \quad$ Recommendation & \\
\cline { 2 - 3 } & $\bullet \quad$ Compliment & Writer-oriented \\
\hline
\end{tabular}

\subsection{Assessment Method for Measuring Argumentative Writing Ability}

How to measure the quality of argumentation is always the concern of students, teachers and researchers for it can check the outcomes to provide drawbacks to argumentative teaching and learning and let the students know how they can improve. So far, various rubrics are applied to testing argumentative writing ability. For example, Qin (2013) employed a holistic rubric in order to examine the effects of applying the Toulmin's model in teaching Turkish university English learners. She proposed five scales: Scale 5-An excellent persuasive argument, Scale 4-A reasonably good and persuasive argument, Scale 3-A clearly recognizable argument but limited in effectiveness, Scale 2-A minimally acceptable argument paper, though not persuasive, and Scale 1-An ineffective argument with major gaps in reasoning (p. 29).

Zainuddin and Shammem (2016) discussed the effects of Toulmin's model of logical reasoning on the high school students' argumentative writing ability. Six scoring criteria revised from Toulmin's model were listed: Claims, data, warrant, propositions, opposition and response. In terms of scoring, claims, data and warrant were rated a score from $0-6$, while propositions, opposition and response were rated from 0 to 3, which indicates that the first three criteria outweigh the rest ones during the process of assessment.

Lam, Hew and Chiu (2018) employed an analytic assessment to investigate the effectiveness of a blended learning approach on improving students' argumentative writing ability in Hong Kong secondary school. Five criteria of key components of argumentative writing were rated on a score from 1 to 4 . They were stating stance and providing evidence from one own thesis, envisioning anti-thesis and their support, evaluating points of view, supports and questionable inferences, providing rebuttals, and supporting conclusion using both thesis and anti-thesis.

By analysis of these assessment methods, it can be found that Toulmin's argumentative model grounded the assessment of argumentative writing. With the guidance of Toulmin's model, argumentative texts are classified into different components and then each component is scored respectively in order to judge the quality of an argumentative essay.

Synthesized the assessing methods above, six criteria for evaluating students' argumentative writing ability are from the six argumentative writing elements: Claim, My side/Your side, Evidence, Warrant, Rebuttal and Conclusion. Five levels corresponding to 1 to 5 points are Minimally Developed, Partially Developed, Generally Developed, Well Developed, and Highly Developed. Each level is described in detailed into six categories. The 5 descriptors for rating students' argumentative writing ability are:

5 means the argumentative writing ability is 'Highly Developed'.

4 means the argumentative writing ability is 'Well Developed'.

3 means the argumentative writing ability is 'Generally Developed'.

2 means the argumentative writing ability is 'Partially Developed'. 
1 means the argumentative writing ability is 'Minimally Developed'.

The assessment criteria of the argumentative writing ability are:

4.01-5.00 means the argumentative writing ability is 'Highly Developed'.

3.01-4.00 means the argumentative writing ability is 'Well Developed'.

2.01-3.00 means the argumentative writing ability is 'Generally Developed'.

1.01-2.00 means the argumentative writing ability is 'Partially Developed'.

0.01-1.00 means the argumentative writing ability is 'Minimally Developed'.

Finally, the scoring rubrics are designed for measuring argumentative writing. Table 2.4 displays the details.

Table 2.4. Rubrics for Assessing Chinese College English Learners' Argumentative Writing Ability

\begin{tabular}{|c|c|c|}
\hline Points & Levels & Description \\
\hline 1 & $\begin{array}{l}\text { Minimally } \\
\text { Developed }\end{array}$ & $\begin{array}{l}\text { The claim is minimally clear and controversial. } \\
\text { The author's and the opponent's positions are hard to identify. } \\
\text { The evidence is minimally effective and convincing. } \\
\text { The evidence is inappropriately interpreted and fails to back up the } \\
\text { author's side. } \\
\text { The counterarguments are minimally refuted. } \\
\text { The conclusion is minimally grounded. }\end{array}$ \\
\hline 2 & $\begin{array}{l}\text { Partially } \\
\text { Developed }\end{array}$ & $\begin{array}{l}\text { The claim is partially clear and controversial. } \\
\text { The author's and the opponent's positions are partially easy to identify. } \\
\text { The evidence is partially effective and convincing. } \\
\text { The evidence is partially interpreted to back up the author's side. } \\
\text { The counter arguments are partially refuted. } \\
\text { - The conclusion is partially grounded with little credibility. }\end{array}$ \\
\hline 3 & $\begin{array}{l}\text { Generally } \\
\text { Developed }\end{array}$ & $\begin{array}{l}\text { The claim is generally clear and controversial. } \\
\text { The author's and the opponent's positions are generally easy to identify. } \\
\text { The evidence is generally effective and convincing. } \\
\text { The evidence is generally interpreted to back up the author's side. } \\
\text { The counterarguments are generally relevantly refuted. } \\
\text { The conclusion is generally grounded with limited credibility. }\end{array}$ \\
\hline 4 & $\begin{array}{l}\text { Well } \\
\text { Developed }\end{array}$ & $\begin{array}{l}\text { The claim is clear, controversial and well-developed. } \\
\text { The author's and the opponent's positions are easy to identify. } \\
\text { The evidence is effective, convincing and well-developed. } \\
\text { The evidence is appropriately interpreted to well back up the author's } \\
\text { side. } \\
\text { The counterarguments are well refuted. } \\
\text { The conclusion is well grounded with credibility. }\end{array}$ \\
\hline 5 & $\begin{array}{l}\text { Highly } \\
\text { Developed }\end{array}$ & $\begin{array}{l}\text { The claim is clear, controversial and fully developed. } \\
\text { The author's and the opponent's positions are fully-developed and easy } \\
\text { to identify. } \\
\text { The evidence is effective, convincing and fully developed. } \\
\text { The evidence is fully interpreted to back up the author's side. } \\
\text { The counterarguments are fully and saliently refuted. } \\
\text { The conclusion is fully grounded with high credibility. }\end{array}$ \\
\hline
\end{tabular}

\section{Conclusions}

How to design a pedagogical framework to facilitate critical thinking skills infusion during argumentative writing process in order to ultimately improve students' argumentative writing ability is discussed from the aspect of explicit instruction of critical thinking skills, teacher's feedback, students' self-reflection and the assessment method. During the phase of explicit instruction of critical thinking skills, six Beyer's stages were introduced; during the teacher's feedback, teacher's written comments together with grading was suggested; during the phase of students' reflection, the reflective cycle with guided questions was proposed. The flowchart of the pedagogical framework is portrayed in Figure 3.1. There is no denying that the practice to teach argumentative writing by the infusion of critical thinking skills is complex. Therefore, the teacher needs to make the pedagogical process clear and simple for the students to follow in order to promote their argumentative writing ability. 


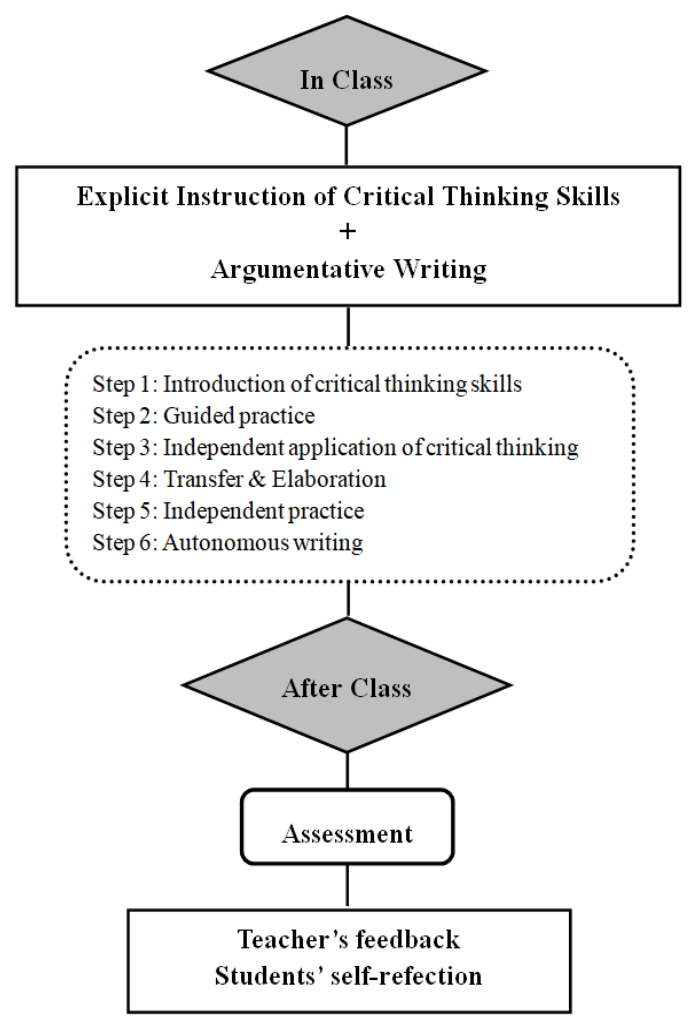

Figure 3.1. Pedagogical Flowchart for Infusing Critical Thinking Skills into Argumentative Writing Class

\section{References}

Abrami, P. C., Bernard, R. M., Borokhovski, E., Wade, A., Surkes, M. A., Tamim, R., \& Zhang, D. (2008). Instructional interventions affecting critical thinking skills and dispositions: A stage 1 meta-analysis. Review of Educational Research, 78(4), 1102-1134.

Beyer, B. K. (1995). Critical thinking. Bloomington, IN: Phi Delta Kappa Educational Foundation.

Bergen, C. W., Bressler, M. S., \& Campbell, K. (2014). The sandwich feedback method: Not very tasty. Journal of Behavioral Studies in Business, 7, 1-13.

Bitchener, J., \& Knoch, U. (2008). The value of written corrective feedback for migrant and international students. Language Teaching Research Journal, 12(3), 409-431.

Black, P. E., \& Plowright, D. (2010). A multi-imensional model of reflective learning for professional development. Reflective Practice, 11(2), 245-258.

Cole, J. (2006). Toxic feedback helping writers survive and thrive. Hanover, N.H.: University Press of New England.

Dellebovi, B. M. (2012). Literacy instruction: From assignment to assessment. Assessing Writing, 17(4), 271-292.

Denny, H. C. (2008). Dangerous liaisons: reflections on a pilot project for state-mandated outcomes assessment of written communication. Assessing Writing, 13(1), 26-44.

Dekeyser, R. (2007). Skill acquisition theory. In B. VanPatten \& J. Williams (Eds.), Theories in second language acquisition: An introduction (pp. 97-113). New Jersey: Lawrence Erlbaum Associates, Inc.

Dixon, Z., \& Moxley, J. (2013). Everything is illuminated: what big data can tell us about teacher commentary. Assessing Writing, 18(4), 241-256.

Emig, J. (1997). Teaching and Assessing Writing. New Jersey, NJ: BuyntonCook Publication Inc.

Ennis, R. H. (1989). Critical thinking and subject specificity: Clarification and needed research. Educational Researcher, 18(3), 4-10. 
Facione, P. A. (1990). Critical thinking: A statement of expert consensus for purposes of educational assessment and instruction. Research findings and recommendations. American Philosophical Association, Newark, DE. (ERIC Document Reproduction Service, No. ED 315423)

Gibbs, G., (1988). Learning by doing: A guide to teaching and learning methods. London: Further Education Unit.

Harmer, J. (2004). How to teach writing. Edinburgh Gate: Person Education Limited, Longman.

Hattie, J., \& Timperley, H. (2007). The Power of Feedback, Review of Educational Research, 77(1), 81-112.

Hong, Y., \& Choi, I. (2011). Three dimensions of reflective thinking in solving design problems: A conceptual model. Educational Technology Research and Development, 59, 687-710.

Huang, Y. S. (2010). English majors' course-setting needs comprehensive reform---rethink the deficiency of critical thinking. Foreign Language World, 1, 11-16.

Hyland, K., \& Hyland, F. (2006). Feedback on second language students' writing. Language Teaching, 39(2), 83-101.

Lam, Y., Hew, K., \& Chiu, K. (2018). Improving argumentative writing: effects of a blended learning approach and gamification. Language Learning \& Technology, 22(1).97-118.

Lu, C. X. (2019). A framework for infusing critical thinking into Chinese college EFL Learners' argumentative writing process. English Linguistic Research, 8(2), 16-20.

Moussa-Inaty, J. (2015). Reflective writing through the use of guiding questions. International Journal of Teaching and Learning in Higher Education, 27(1), 104-113.

Mu, C. J. (2016). Investigating English major students' critical thinking ability in academic writing. Modern Foreign Languages, 39(5), 693-703.

Nattawut, N., \& Dumrong, A. (2019). An Initial Development of an Analytic for Assessing Critical Thinking in English Argumentative Essays of EFL College Students. rEFLections, 26(2), 51-71.

Nippold, M. A., Wardlonergan, J. M., \& Fanning, J. L. (2005). Persuasive writing in children, adolescents, and adults: a study of syntactic, semantic, and pragmatic development. Language Speech \& Hearing Services in Schools, $36(2), 125-138$.

Parkin, J. H, Hepplestone, S., Holden, G., Irwin, B., \& Thorpe, L. (2012). A role for technology in enhancing students' engagement with feedback, Assessment \& Evaluation in Higher Education, 37(8), 963-973.

Qin, J. J. (2013). Applying the Toulmin Model in Teaching L2 Argumentative Writing. The Journal of Langue Teaching and Learning, 2, 21-29.

Schön, D. A. (1987). Educating the reflective practitioner: Toward a new design for teaching and learning in the professions. San Francisco: Jossey Bass.

Sharples, M. (1999). How we write as creative design. London: Routledge.

Sun, Y. Z. (2011). On writing instruction of English majors and cultivation of critical thinking ability. Foreign Language Teaching and Research (bimonthly), 4, 603-608.

Sun, Y. Z. (2019). Principles of language and critical thinking integrated teaching, Foreign Language Teaching and Research (bimonthly), 51(6), 825-837.

Swartz, R. (2001). Infusing the Teaching of Critical and Creative Thinking into Content Instruction. Developing Minds, Association of Supervision and Curriculum Development, Alexandria, Virginia.

Wen, Q. F., \& Sun M. (2015). On key issues about critical thinking development in college EFL classroom. Foreign Language Learning Theory and Practice, 3, 6-12.

Zainuddin, Z., \& Shammem, R. G. (2016). Effects of training in the use of Toulmin's Model on ESL students' argumentative writing and critical thinking ability. Malaysian Journal of Language and Linguistics, 5(2), 114-133.

\section{Copyrights}

Copyright for this article is retained by the author(s), with first publication rights granted to the journal.

This is an open-access article distributed under the terms and conditions of the Creative Commons Attribution license (http://creativecommons.org/licenses/by/4.0/). 